\title{
How Far Can The Golden Mussel (Limnoperna Fortunei - Mytilidae) Go With Its Own Foot?
}

\author{
Pereira SM, Colares EP and Vieira JP* \\ Federal University of Rio Grande, Brazil \\ *Corresponding author: Joao Paes Vieira, Laboratory of Ichthyology, Federal \\ University of Rio Grande, Campus Carreiros, Brazil, Tel: +55 (53) 32336539; E-mail: \\ vieira@mikrus.com.br
}

\section{Review Article \\ Volume 2 Issue 4}

Received Date: May 27, 2019

Published Date: July 01, 2019

DOI: $10.23880 /$ izab- 16000160

\section{Abstract}

Limnoperna fortunei (golden mussel) displays significant invasive potential and can lead to economic and environmental damage. The aim of this study is to describe the ontogenetical circadian pattern of activity of golden mussel using laboratory experiments. Golden mussels were split into two size groups: small $(<15 \mathrm{~mm})$ and large $(>=15 \mathrm{~mm})$. The movement pattern of each size group was filmed. Experiments were carried out in two distinct periods: light-dark experiments comprising 9 hours under a bright light followed by 13 hours under a red light and dark-light experiments consisting of 13 hours under a red light followed by 9 hours under a bright light. The variables course and speed were tested using size (small and large) and experiments (light-dark and dark-light) as factors. Both small and large mussels were more active in the first eight hours of the experiments, but no differences were observed regarding course and speed between the experiments. The period of the day did not influence the activity or distance patterns traveled by golden mussels, although small golden mussels presented significantly higher mean course and speed significantly compared to large mussels. Small individuals also displace faster than large individuals, resulting in longer traveled distances.

Keywords: Behavior; Experiments; Freshwater; Invasive Species; Locomotion

\section{Introduction}

Limnoperna fortunei (DUNKER 1857), popularly known as the golden mussel, is a bivalve belonging to the Mitilidae family originated from Southeast Asia rivers and streams [1]. Pastorino, et al. [2] recorded this species for the first time in the La Plata River, South America, near Buenos Aires, Argentina, in 1991, where it was probably introduced by ballast water. Ten years after the first record of the golden mussel in the La Plata River, a 3,000 $\mathrm{Km}$ increase $(250 \mathrm{Km} /$ year $)$ in this species upstream distribution along the bay was observed [3]. Until 2014, the South American L. fortunei range seemed to be limited to the large La Plata River basin (comprising the Paraguay, Parana and Uruguay rivers) and some minor watersheds (Guaiba; Patos-Mirim Lagoon and Tramandai, in Brazil and Mar Chiquita, in Argentina) [4]. However, it is currently found in several South American regions [5], and, recently, Barbosa, et al. [6] reported its occurrence in the São Francisco River basin, in northeastern Brazil [7]. Risk Invasion Models also predict a high risk invasion in both north and northeastern Brazil by 2030 and 2050, respectively [8]. 


\section{International Journal of Zoology and Animal Biology}

Pioneer studies concerning the presence of L. fortunei in the Patos-Mirim system have evinced that its invasion and spreading occurred from the Guaiba River, in 1998 [9]. After these first records, the species was reported downstream, south, at the Patos Lagoon $[10,11]$, entering the estuarine region of the São Gonçalo Channel. After trespassing the waterway that connects the Patos Lagoon to the Mirim Lagoon, it began its expansion into the Mirin Lagoon, the second largest coastal lagoon in southern Brazil bordering Uruguay [11-15].

A significant similarity in morphology, size and behavior between marine and freshwater mussels is noted [16], and three major life cycle periods of these animals are observed, namely larval, juvenile and adult stages. Many studies have been carried out on the settlement behavior of golden mussel larvae and the initial post-larvae phases $[17,18]$. The "pediveliger" stage is considered by some authors as the last larval stage. Between the larval and juvenile stages ("plantigrade") the mussel is able to secrete byssus threads, allowing for its attachment to substrates $[16,19]$. After settling on the substrate, they move only by crawling, which allows them to climb and aggregate. This behavior has been also described for several freshwater mussels [16,20-27], revealing that juvenile golden mussels can crawl over several substrates and re-establish in new locations after suffering disturbances, [21,28-30]. However, a lack of research on the movement pattern of adults is observed $[20,30,31]$, mainly because it is hardly imagined that adult mussels would move after becoming fixed by their byssus [31].

Experimental studies are essential to understand ontogenetic golden mussel taxis differences [32]. The fact that this species has invaded several environments demonstrated its great versatility, offering a unique opportunity to study the invasive behavior of a highly aggressive species $[5,19,33]$. Lopes \& Vieira, et al. [28] and Vieira, et al. [29] have demonstrated that fish feeding on $L$. fortunei in nature involves the selective consumption of smaller size classes. The authors suggested that enhanced predation of smaller mussels might be due to the fact small individuals are usually located on the bottom before they find a hard substrate, and that they move around more often than larger individuals. However, according to Cataldo, et al. [34], direct evidence of this effect is lacking. In this context, the aim of this study is to analyze the taxis pattern of distinct golden mussel size classes through laboratory experiments. The working hypothesis is that golden mussel movement (course and speed) is similar regardless of size or time of day.

\section{Material and Methods}

\section{Organism Collection Area}

Golden mussel stocks were renewed monthly through sampling carried out at the São Gonçalo Channel, RS, Brazil (31 ${ }^{\circ} 49^{\prime} 3.85^{\prime \prime} S$; $\left.52^{\circ} 23^{\prime} 32.60^{\prime \prime} 0\right)$. The animals were transported in plastic containers with local water and taken to Rio Grande Federal University (FURG) adhered to the original substrate from the sampling location.

At the laboratory, animals were maintained in aquariums containing water from the environment, aerated at $20 \mathrm{o} \mathrm{C}$. The mussels were fed at two to three days intervals with a microalgae concentrate. After one month in the lab, whether or not they were used in the experiments, golden mussels were euthanized through sodium hypochlorite addition to the water at high concentrations, eliminating both adults and larvae, and then disposed of.

Total shell length (TL $\mathrm{mm}$ ) was determined using a digital caliper. Individuals were classified into two size groups (small $-\mathrm{S}<15 \mathrm{~mm}$ TL and large $-\mathrm{L}>=15 \mathrm{~mm} \mathrm{TL}$ ). Each individual was used only once in the experiments. The dislodgement experiments were carried out for a maximum of $22 \mathrm{~h}$ and the golden mussels were not fed during the experiments. The water used in experiments was collected from the Rio Grande municipality public supply and aerated for at least 96 hours before experiments for chlorine elimination.

\section{Taxis Experiments}

All experiments were conducted individually. One golden mussel was placed in the center of a plastic box (internal dimensions: $34 \mathrm{~cm}$ height and 32 by $65.5 \mathrm{~cm}$ by side) with a griddled background (1 square $\mathrm{cm}$ ). The box was filed with water up to $3 \mathrm{~cm}$. A DCR-SR68 Sony video camera was used to record displacement over $22 \mathrm{~h}$. To observe possible behavior alterations in circadian rhythms, the experiments began in two distinct periods: 1) beginning at $9 \mathrm{am}$, consisting in bright light exposure from 9 am to $6 \mathrm{pm}$ and red light exposure under reduced luminosity from $6 \mathrm{pm}$ to $07 \mathrm{am}$, termed light-dark experiments (L-D); 2) beginning at $7 \mathrm{pm}$ comprising red light exposure until 8 am and bright light exposure from 8 am to $5 \mathrm{pm}$, termed dark-light experiments (D-L).

\section{Data Analysis}

The course sum (C) was defined as the sum of individual tracks during each experiment. Activity hours (Ha) were defined as the sum of the number of hours in which the course was concluded. Speed (Sp) was defined 
as the sum of the individual course divided by the activity hours. To test for statistical differences between $\mathrm{C}, \mathrm{S}$ and Ha between golden mussels size groups ( $(S$ and $L$ ) and type of experiment (L-D and D-L), a two way analysis of variance (ANOVA; experiment $\mathrm{x}$ group size) was applied, followed by Tukey's test [35]. To verify golden mussel individual size (TL) influence on course, a simple regression analysis was performed using the $\mathrm{R}$ software, considering the golden mussels used in all experiments. Golden mussels considered dead or with no apparent locomotion during the $22 \mathrm{~h}$ in each experiment were not analyzed.

\section{Results}

\section{Comparison Between Experiments D-L and L-D}

Tables 1, 2 and 3 indicate that the sum of course (C), average speed (Sp) and hours of activity (Ha) displayed no significant interaction between the experimental factors related to daylight period (L-D and D-L) and group size (S and L). No significant differences were observed for hours of activity between group size and between periods (Table 3). Course and speed also displayed no statistics differences between periods. Small golden mussels showed significantly higher course means (C Small $=109 \mathrm{~cm}+/-$ SD 65) $(\mathrm{p}=0.0002)$ compared to large specimens (C Large $=24 \mathrm{~cm}+/-$ SD 26) (Table 1). The equation that describes the relationship between size and course is given by Course $=273.969-14.113 \times$ size $(\mathrm{R} 2=0.53 ; \mathrm{p}=0.000001)$. Small golden mussels showed significantly higher mean speed (Sp Small $=23 \mathrm{~cm} / \mathrm{h}+/-\mathrm{SD}$ 9.3) $(p=0.0001)$ compared to larger individuals (Sp Large $=5.3 \mathrm{~cm} / \mathrm{h}+/-\mathrm{SD} 4.8$ ) (Table 2). The equation that describes the relationship between size and speed is given by Speed $=51.2615-2.5446 \quad x$ size $\quad(R 2=0.57$; $\mathrm{p}=0.0000004)$.

The smaller the golden mussel, the greater the distance traveled. The maximum distance traveled by one individual measuring $7.4 \mathrm{~mm}$ TL was $285 \mathrm{~cm}$ during $10 \mathrm{~h}$, speeding up to $60 \mathrm{~cm}$ in one hour (Table 4).

\begin{tabular}{|c|c|c|c|c|c|}
\hline Course & MS & DF & SS & F & P \\
\hline SIZE & 3.956 & 1 & 3.956 & 18.47 & $0.000^{*}$ \\
\hline PERIOD (L-D*D-L) & 0.05 & 1 & 0.05 & 0.23 & 0.634 \\
\hline SIZE*PERIOD & 0.393 & 1 & 0.393 & 1.83 & 0.187 \\
\hline
\end{tabular}

Table 1: Two-way analysis of variance (ANOVAS) for course. MS=medium square, $\mathrm{DF}=$ degrees of freedom, $\mathrm{SS}=\mathrm{sum}$ of squares, $\mathrm{F}=$ variance between groups, $\mathrm{P}=$ probability that the null hypothesis is true.

\begin{tabular}{|c|c|c|c|c|c|}
\hline Speed & MS & DF & SS & F & P \\
\hline SIZE & 1.733 & 1 & 1.733 & 20.71 & $0.000^{*}$ \\
\hline PERIOD (L-D*D-L) & 0.019 & 1 & 0.019 & 0.23 & 0.637 \\
\hline SIZE*PERIOD & 0.351 & 1 & 0.351 & 4.19 & 0.051 \\
\hline
\end{tabular}

Table 2: Two-way analysis of variance (ANOVA) for speed. MS=medium square, DF=degrees of freedom, SS = sum of squares, $\mathrm{F}=$ variance between groups, $\mathrm{P}=$ probability that the null hypothesis is true.

\begin{tabular}{|c|c|c|c|c|c|}
\hline Hours of activity & MS & DF & SS & F & P \\
\hline SIZE & 0.174 & 1 & 0.174 & 3.533 & 0.07 \\
\hline PERIOD (L-D*D-L) & 0.068 & 1 & 0.068 & 1.381 & 0.25 \\
\hline SIZE*PERIOD & 0.009 & 1 & 0.009 & 0.174 & 0.68 \\
\hline
\end{tabular}

Table 3: Two-way analysis of variance (ANOVA) for hour of activity. MS=medium square, DF=degrees of freedom, $\mathrm{SS}=$ sum of squares, $\mathrm{F}=$ variance between groups, $\mathrm{P}=$ probability that the null hypothesis is true.

Based on the fact that no statistical differences were observed for the studied parameters between the experimental periods, all individuals belonging to the same size groups ( $\mathrm{S}$ and $\mathrm{L}$ ) were analyzed together and the activity pattern of each size group was described separately. Fourteen small $(<15 \mathrm{~mm}$ TL) and 17 large $(>=15 \mathrm{~mm}$ TL) golden mussels were used for this analysis. Tables 4 and 5 and Figure 1 demonstrate that, regardless of size class ( $\mathrm{S}$ and $\mathrm{L}$ ), golden mussels are more active in the initial periods of the experiments, displaying peak activity in the 6th and 7th hour after the beginning of the experiments, respectively. No activity was observed after 19 hours of experiments (Figure 1). One of the large golden mussels, did not move during the experiment (Table 4). 


\section{International Journal of Zoology and Animal Biology}

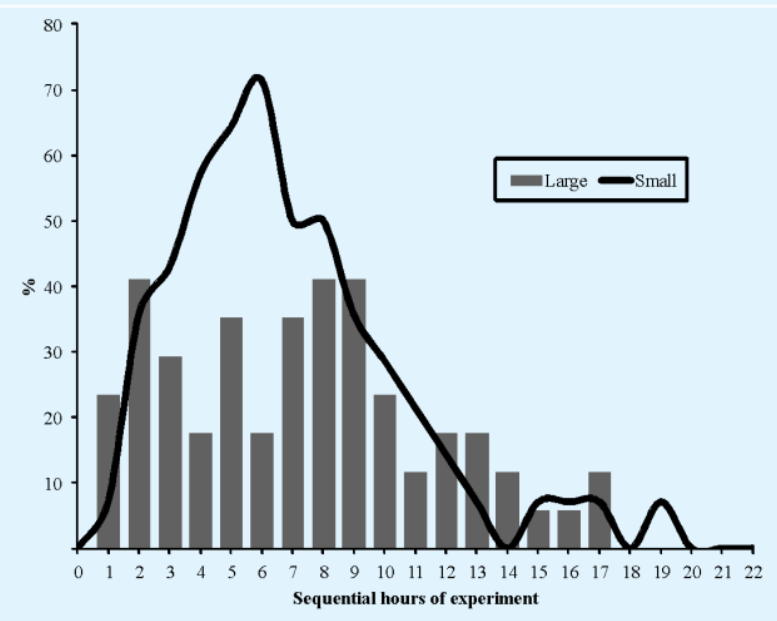

Figure 1: Activity frequency (\%) for all small (line) and large (block) golden mussels during 22 hours.

\begin{tabular}{|c|c|c|c|c|c|c|c|c|c|c|c|c|c|c|c|c|}
\hline \multicolumn{17}{|c|}{ Small } \\
\hline Size & 11 & 14.4 & 13.8 & 11.7 & 9.7 & 13.7 & 7.4 & 11.5 & 10 & 14.3 & 12.5 & 14 & 13.4 & 12.9 & & \\
\hline SH & $\mathbf{A}$ & B & C & D & $\mathbf{E}$ & $\mathbf{F}$ & G & H & I & $\mathbf{J}$ & $\mathbf{K}$ & L & $\mathbf{M}$ & $\mathbf{N}$ & Sum & \%Ativ \\
\hline 1 & 12 & & & & & & & & & & & & & & 12 & 7.1 \\
\hline 2 & 24 & 1 & 4 & 26 & 33 & & & & & & & & & & 88 & 35.7 \\
\hline 3 & 35 & & 28 & 23 & 54 & 1 & 8 & & & & & & & & 149 & 42.9 \\
\hline 4 & 19 & 5 & 27 & 41 & 13 & 3 & 60 & 12 & & & & & & & 180 & 51.7 \\
\hline 5 & 23 & 45 & 11 & 11 & & 24 & 31 & 40 & 6 & 8 & & & & & 199 & 64.3 \\
\hline 6 & 9 & 14 & 10 & & & 24 & 38 & 32 & 48 & 23 & 8 & 19 & & & 235 & 71.4 \\
\hline 7 & & & & & & 14 & 34 & 22 & 48 & 28 & 45 & 40 & & & 231 & 50 \\
\hline 8 & & & & & & 1 & 36 & 15 & 23 & 11 & 21 & 41 & & & 183 & 50 \\
\hline 9 & & & & & & 5 & 23 & 16 & & & & 41 & 3 & & 88 & 35.7 \\
\hline 10 & & & & & & & 29 & & & & & 24 & 3 & 40 & 96 & 28.6 \\
\hline 11 & & & & & & & 29 & & & & & 23 & & 33 & 85 & 21.4 \\
\hline 12 & & & & & & & 7 & & & & & 5 & & & 12 & 14.3 \\
\hline 13 & & & & & & & & & & & & & 1 & & 1 & 7.1 \\
\hline 14 & & & & & & & & & & & & & & & 0 & 0 \\
\hline 15 & & & & & & & & & & & & & 1 & & 1 & 7.1 \\
\hline 16 & & & & & & & & & & & & & 3 & & 3 & 7.1 \\
\hline 17 & & & & & & & & & & & & & 1 & & 1 & 7.1 \\
\hline 18 & & & & & & & & & & & & & & & 0 & 0 \\
\hline 19 & & & & & & & & & & & & & 4 & & 4 & 7.1 \\
\hline 20 & & & & & & & & & & & & & & & 0 & 0 \\
\hline 21 & & & & & & & & & & & & & & & 0 & 0 \\
\hline 22 & & & & & & & & & & & & & & & 0 & 0 \\
\hline $\mathrm{Ha}$ & 6 & 4 & 5 & 4 & 3 & 7 & 10 & 6 & 4 & 4 & 3 & 7 & 7 & 2 & & \\
\hline $\mathrm{C}$ & 122 & 65 & 80 & 101 & 100 & 72 & 285 & 137 & 125 & 80 & 74 & 193 & 16 & 73 & & \\
\hline $\mathrm{Sp}$ & 20.3 & 16.3 & 16 & 25.3 & 3.3 & 10.3 & 28.5 & 22.8 & 31.3 & 20 & 24.7 & 27.6 & 2.3 & 36.5 & & \\
\hline
\end{tabular}

Table 4: Activity pattern per hour of small $(<15 \mathrm{~mm})$ golden mussels. Mussel size, in $\mathrm{mm}$. $\mathrm{SH}=$ sequential hours of the experiment. Each letter represents an individual. Sum= sum of the traveled distances by mussels in a particular hour; \%Ativ= percent of active mussels in a particular hour; Ha= hours of activity; $\mathrm{C}=$ sum of courses; $\mathrm{Sp}=$ average speed. 


\section{International Journal of Zoology and Animal Biology}

\begin{tabular}{|c|c|c|c|c|c|c|c|c|c|c|c|c|c|c|c|c|c|c|c|}
\hline \multicolumn{20}{|c|}{ Large } \\
\hline Size & 19 & 19 & 17 & 15 & 22 & 17 & 15 & 15 & 17 & 18 & 19 & 16 & 16 & 16 & 16 & 13 & 16 & & \\
\hline SH & $\mathbf{A}$ & B & C & D & $\mathbf{E}$ & $\mathbf{F}$ & $\mathbf{G}$ & $\mathbf{H}$ & I & $\mathbf{J}$ & $\mathbf{K}$ & $\mathbf{L}$ & $\mathbf{M}$ & $\mathbf{N}$ & 0 & $\mathbf{P}$ & $\mathbf{Q}$ & Sum & \%Ativ \\
\hline 1 & & 3 & 6 & 7 & 8 & & & & & & & & & & & & & 24 & 23.5 \\
\hline 2 & & 19 & 29 & 1 & 1 & 1 & 2 & 9 & & & & & & & & & & 62 & 41.2 \\
\hline 3 & & 4 & 24 & & & & 1 & 3 & 1 & & & & & & & & & 33 & 29.4 \\
\hline 4 & & & 12 & & 6 & & & & 1 & & & & & & & & & 19 & 17.6 \\
\hline 5 & & & 6 & 5 & 6 & & & & & 0.5 & 1 & 1 & & & & & & 19 & 29.4 \\
\hline 6 & & & & & & & & & & & 2 & 17 & 8 & & & & & 27 & 17.6 \\
\hline 7 & & & 8 & & & & & & & 0.5 & 1 & 20 & 5 & 1 & & & & 35 & 29.4 \\
\hline 8 & & & 5 & & & & & & & 0.5 & 1 & 11 & 18 & 2 & 15 & & & 52 & 35.3 \\
\hline 9 & & & 2 & & & & & & & 1 & & 9 & 8 & 2 & 12 & 1 & & 35 & 41.2 \\
\hline 10 & & & 2 & & & & & & 8 & 1 & & & & 0.5 & & & & 11 & 17.6 \\
\hline 11 & & & & & & & & & & & & & & 4 & 2 & & & 6 & 11.8 \\
\hline 12 & & & & & & & & & & 1 & & & & & 17 & & 19 & 37 & 17.6 \\
\hline 13 & & & & & & & & & & 2 & & & & & 6 & & 17 & 25 & 17.6 \\
\hline 14 & & & & & & & & & & 1 & & & & & & & 8 & 9 & 11.8 \\
\hline 15 & & & & & & & & & & 1 & & & & & & & & 1 & 5.9 \\
\hline 16 & & & & & & & & & & & & & & & 2 & & & 2 & 5.9 \\
\hline 17 & & & & & & & & & & 1 & & & & & 6 & & & 7 & 11.8 \\
\hline 18 & & & & & & & & & & & & & & & & & & 0 & 0 \\
\hline 19 & & & & & & & & & & & & & & & & & & 0 & 0 \\
\hline 20 & & & & & & & & & & & & & & & & & & 0 & 0 \\
\hline 21 & & & & & & & & & & & & & & & & & & 0 & 0 \\
\hline 22 & & & & & & & & & & & & & & & & & & 0 & 0 \\
\hline $\mathrm{Ha}$ & 0 & 3 & 9 & 3 & 4 & 1 & 2 & 2 & 3 & 10 & 4 & 5 & 4 & 5 & 7 & 1 & 3 & & \\
\hline C & 0 & 26 & 94 & 13 & 21 & 1 & 3 & 12 & 10 & 9.5 & 5 & 58 & 39 & 9.5 & 60 & 1 & 44 & & \\
\hline Sp & 0 & 8.7 & 10.4 & 4.3 & 5.3 & 1 & 1.5 & 6 & 3.3 & 1 & 1.3 & 11.6 & 9.8 & 1.9 & 8.6 & 1 & 14.7 & & \\
\hline
\end{tabular}

Table 5: Activity pattern per hour of large (>= $15 \mathrm{~mm}$ ) golden mussels. Mussel size, in $\mathrm{mm}$. SH = sequential hours of the experiment. Each letter represents an individual. Sum= sum of the traveled distances by mussels in a particular hour; \%Ativ= percent of active mussels in a particular hour; $\mathrm{Ha}=$ hours of activity; $\mathrm{C}=$ sum of courses; $\mathrm{Sp}=$ average speed.

\section{Discussion}

Assessments concerning self-propelling golden mussel movements are underestimated and deserve greater consideration, providing better understanding of driver dispersion and ecological interactions [30,36,37]. The working hypothesis of the present study was that the golden mussel movement (course and speed) is similar regardless of size and time of day.

No taxis behavior changes were observed for either small $(<15 \mathrm{~mm} \mathrm{TL})$ or large $(>=15 \mathrm{~mm} \mathrm{CT})$ individuals after the lights of the experiment were turned on or off. No statistical differences in distance and speed were observed for experiments that began in either light or dark situations. These findings are novel and partially support the hypothesis that the period of the day does not influence activity patterns or distance traveled by golden mussels after settlement.
Both small and large mussels showed a considerable ability to move with a certain taxis, revealing that these individuals are able to re-settle to new locations just after handling. This behavior enhances the chance of selecting safer sites (e.g. crevices) or attaching themselves to neighbors via byssal threads, thereby providing mutual protection $[21,31,38]$.

Both small and large mussels were more active in the first eight hours of the experiments. Small individuals dislodge themselves significantly faster than large individuals, resulting in high traveled distance. Jager, et al. [38] report that young mussels can detach themselves and search for better locations, while Lopes \& Vieira [39] and Vieira \& Lopes [29] demonstrate that small golden mussel are more frequently found in fish guts than large individuals. These authors suggest that the significant predation of smaller mussels might be due to the fact that small individuals who settled in soft bottom wander more 


\section{International Journal of Zoology and Animal Biology}

often and travel large distances before finding a hard substrate, shelter or conglomeration. This ability has important implications for biofouling control and likely represent adaptive responses, enhancing mussel survival and invasive power $[31,37]$.

Our experiment duration $(22 \mathrm{~h})$ does not allow for the conclusion if motionless individuals return to motion after 22 hours. It is probable that golden mussels can return to motion in a period exceeding the experiments carried out herein [37]. This is supported by casual observations in the laboratory indicating that sessile golden mussels may display sporadic movements on aquarium walls after more than a day of settlement.

The detection of invasive species is an important management consideration, but once a population of golden mussels has become established in a water body, there is very little to be done to remove them [40], and prevention is the best way to maintain a water body free of golden mussels.

\section{Conclusion, Future Directions and Recommendations}

Three major golden mussel life cycle periods are observed in nature: larvae, juvenile and adult stages. Many studies have been conducted on detecting larvae and adults, but sampling methods that focus on detecting small individual abundance and distribution are scarce [4].

Both small and large mussels were more active in the first hours of the experiments, but the period of the day did not influence the activity or distance patterns traveled. Small golden mussels presented significantly higher mean course, speed and displace faster compared to large mussels.

Future experiments and field collections should be carried out on the displacement of small individuals, as well as relative abundance measurements, in order to improve knowledge on invasive power of this species.

\section{Acknowledgments}

The authors would like to thank CNPq (Conselho Nacional de Desenvolvimento Científico e Tecnológico) for personal grants. SMP is a former postgraduate student of the Biologia de Ambientes Aquáticos Continentais program, FURG.

\section{References}

1. Ricciardi A (1998) Global range expansion of the asian mussel Limnoperna fortunei (Mytilidae): Another fouling threat to freshwater systems. Biofouling 13(2): 97-106.

2. Pastorino G, Darrigran G, Martin S, Lunaschi L (1993) Limnoperna fortunei (Dunker, 1857) (Mytilidae) nuevo bivalvo invasor en aguas del Rio de la Plata. Neotropica 39: 101-102.

3. Karatayev AY, Padilla DK, Minchin D, Boltovskoy D, Burlakova LE (2007) Changes in global economies and trade: the potential spread of exotic freshwater bivalves. Biological Invasions 9(2): 161-180.

4. Boltovskoy D (2015) Limnoperna fortunei. The ecology, distribution and control of a swiftly spreading invasive fouling mussel. 10: 476.

5. Darrigran G, Damboronea C (2006) Bio-invasion of the golden mussel in the American continent.

6. Barbosa NPU, Silva FA, Oliveira MD, Neto MAS, De Carvalho MD, et al. (2016) Limnoperna fortunei (Dunker, 1857) (Mollusca, Bivalvia, Mytilidae): first record in the São Francisco River basin, Brazil. Check List 12(1): 1846.

7. Pessotto MA, Nogueira MG (2018) More than two decades after the introduction of Limnoperna fortunei (Dunker 1857) in La Plata Basin. Brazilian Journal Biology 78(4): 773-784.

8. Barbosa N, Ferreira J, Nascimento C, Silva F, Carvalho $\mathrm{V}$, et al. (2018) Prediction of future risk of invasion by Limnoperna fortunei (Dunker, 1857) (Mollusca, Bivalvia, Mytilidae) in Brazil with cellular automata. Ecological Indicators 92: 30-39.

9. Mansur MCD, Richinitti LMZ, Santos CP (1999) Limnoperna fortunei (Dunker, 1857) molusco bivalve invasor na bacia do Guaíba, Rio Grande do Sul, Brasil. Biociências 7(2): 147-149.

10. Mansur MCD, Santos CP, Darrigran G, Heydrich I, Callil CT, et al. (2003) First qualitative-quantitative data of the golden mussel, Limnoperna fortunei (Dunker), the Jacuí Delta, Guaíba Lake and Laguna dos Patos, Rio Grande do Sul, Brazil and some aspects of its invasion in the new environment. Brazilian Journal of Zoology 20(1): 75-84. 


\section{International Journal of Zoology and Animal Biology}

11. Capítoli RR, Colling LA, Bemvenuti CE (2008) Distribution scenarios of the golden mussel Limnoperna fortunei (Mollusca - Bivalvia) under different salinity conditions In the Patos - Mirim lagoon complex, RS - Brazil. Atlântica, 30(1): 35-44.

12. Brugnoli E, Clemente J, Boccardi L, Borthagaray A, Scarabino F (2005) Golden mussel Limnoperna fortunei (Bivalvia: Mytilidae) distribution in the main hydrographical basins of Uruguay: updates and predictions. Anais da Academia Brasileira de Ciencias, 77(2): 235-244.

13. Langone JA (2005) Notas sobre el mejillón dorado Limnoperna fortunei (Dunker, 1857) (Bivalvia, Mytilidae) en Uruguay. Publicación extra del Museo Nacional de Historia Natural y Antropologia Montevideo 1: 1-17.

14. Burns MDM, Garcia AM, Bemvenuti MA, Vieira JP, Marques DMLM, et al. (2006) Bivalvia, Mytilidae, Limnoperna fortunei: Notes on Geographic Distribution. Check list 2(2): 41-43.

15. Colling LA, Pinotti RM, Bemvenuti CE (2012) Limnoperna fortunei na Bacia da Lagoa dos Patos e Lagoa Mirim, p. 187-191. In: Mansur MC, Santos CP, Pereira D, Paz ICP, Zurita MLD, Raya Rodruguez MT, Nerhke MV, Bergonci PEA (Eds.), Moluscos límnicos invasores no Brasil: biologia, prevenção e controle. Porto Alegre: Redes Editora.

16. Ackerman JD, Sim B, Nichols SJ, Claudi R (1994) A review of the early life history of zebra mussels (Dreissena polymorpha): comparisons with marine bivalves. Canadian Journal Zoology 72(7): 1169-1179.

17. Nakano D, Kobayashi T, Sakaguchi I (2010) Predation and depth effects on abundance and size distribution of an invasive bivalve, the golden mussel Limnoperna fortunei, in a dam reservoir. Limnology 11(3): 259266.

18. Nakano D, Kobayashi T, Endo N, Sakaguchi I (2011) Growth rate and settlement of Limnoperna fortunei a temperate reservoir. Journal of Molluscan Studies 77(2): 142-148.

19. Santos CP, Würding NL, Mansur MCD (2005) Larval stages of the golden mussel Limnoperna fortunei (Dunker) (Mollusca, Bivalvia, Mytilidae) in the Guaíba Basin, Rio Grande do Sul, Brazil. Brazilian Journal of Zoology 22(3): 702-708.
20. Uryu $Y$, Iwasaky K, Hinque M (1996) Laboratory experiments on behaviour and movement of a freshwater mussel, Limnoperna fortunei (DUNKER). Journal of a Molluscan studies 62(3): 327-341.

21. Cândido LTS, Romero SMB (2006) Heart rate and burrowing behavior in the mussel Anodontites trapesialis (Bivalvia: Mycetopodidae) from lotic and lentic sites. Comp Biochem Physiol A Mol Integr Physiol 145(1): 131-136.

22. Schwalb AN, Pusch MT (2007) Horizontal and vertical movements of unionid mussels in a lowland river. Journal North American Benthological Society 26(2): 261-272.

23. Allen DC, Vaughn CC (2009) Burrowing behavior of freshwater mussels in experimentally manipulated communities. Journal of the North American Benthological Society 93(1): 93-100.

24. Kobak A, Potznanska M, Kakareko T (2009) Effect of attachment status and aggregation on the behavior of the zebra mussel Dreissena polymorpha. Journal of Molluscan Studies 75(2): 119-126.

25. Kobak J, Kakareko T, Poznańska M (2010) Changes in attachment strength and aggregation of zebra mussel, Dreissena polymorpha in the presence of potential fish predators of various species and size. Hydrobiologia 644(1): 195206.

26. Lara G, Parada E (2009) Substrate selection by the freshwater mussel Diplodon chilensis (Gray, 1828): Field and laboratory experiments. Journal of Molluscan Studies 75(2): 153-57.

27. Kappes H, Haase P (2012) Slow, but steady: dispersal of freshwater mollusks. Aquatic Science 74(1): 1-14.

28. Lopes MN, Vieira JP (2012a) Space-time variation of the relative abundance of Limnoperna fortunei in deep zones of São Gonçalo Channel, Rio Grande do Sul, Brazil. Iheringia, Série Zoologia 102(4): 370-374.

29. Vieira JP, Lopes MN (2013) Size-selective predation of the catfish Pimelodus pintado (Siluriformes: Pimelodidae) on the golden mussel Limnoperna fortunei (Bivalvia: Mytilidae). Zoologia 30(1): 43-48.

30. Iwasaki K (2015) Behavior and Taxis of Young and Adult Limnoperna fortunei in: Boltovskoy, et al. Limnoperna fortunei. The Ecology, Distribution and Control of a Swiftly Spreading Invasive Fouling Mussel. Pp: 249-261. 


\section{International Journal of Zoology and Animal Biology}

31. Iwasaki K (1997) Claiming Behaviour and Tolerance to Aerial Exposure of a freshwater Mussel, Limnoperna fortunei. Japanese journal of malacology 56(1): 15-25.

32. Morton B (1982) The population dynamics of Limnoperna fortunei (Dunker, 1857) (Bivalvia: Mytilacea) in Plover Cove Reservoir, Hong Kong. Malacologia 16(1): 165-182.

33. Karatayev AY, Burlakova LE, Karatayev VA (2010) Limnoperna fortunei Versus Dreissena polymorpha: Population Densities and Benthic Community Impacts of Two Invasive Freshwater Bivalves. Journal of Shellfish Research 29(4): 975-984.

34. Cataldo D (2015) Larval Development of Limnoperna fortunei in Boltovskoy D, et al. (Eds.), The ecology, distribution and control of a swiftly spreading invasive fouling mussel. 10: 476.

35. Zar JH (1999) Biostatistical Analysis. Prentice Hall, New Jersey, USA.

36. Toomey MB, McCabe D, Marsden JE (2002) Factors affecting the movement of adult zebra mussels (Dreissena polymorpha). Journal of North American Benthological Society 21(3): 468-475.
37. Duchini D, Boltovskoy D, Sylvester F (2015) Detachment, displacement and reattachment activity in a freshwater byssate mussel (Limnoperna fortunei): the effects of light, temperature and substratum orientation. Biofouling 31(7): 599-611.

38. Jager M, Weissing FJ, Herman PMJ, Nolet BA, Koppel JV (2011) Lévy Walks Evolve Through Interaction Between Movement and Environmental Complexity (Supporting Online Material). Science 332: 15511553.

39. Lopes MN, Vieira JP (2012b) Predadores potenciais para o controle do mexilhão-dourado. In: Mansur MC, Santos CP, Pereira D, Paz ICP, Zurita MLD, Raya Rodruguez MT, Nerhke MV, Bergonci PEA (Eds.), Moluscos límnicos invasores no Brasil: biologia, prevenção e controle. Porto Alegre: Redes Editora pp: 357-363.

40. Ernandes Silva J, Pinha GD, Mormul RP (2017) Environmental variables driving the larval distribution of Limnoperna fortunei in the upper Paraná River floodplain, Brazil. Acta Limnologica Brasiliensia 29: e108. 